\title{
院外洗浄滅菌システムを導入した急性期病院における 中央滅菌材料部の計画と運用に関する調査研究 \\ A STUDY ON THE PLANNING AND MANAGEMENT \\ OF THE CENTRAL STERILE SUPPLY DEPARTMENT \\ IN ACUTE HOSPITAL HAVING INSTALLED OFF-SITE STERILIZATION SERVICE
}

\author{
石橋達勇*, 中野明** \\ Tatsuo ISHIBASHI and Akira NAKANO
}

\begin{abstract}
This paper describes the characteristics of planning and management of central sterile supply department (C.S.S.D.) in acute hospital having installed off-site sterilization service. We concluded the following points.

1) Hospitals having installed off-site sterilization service conduct a high number of surgical procedures in relation to the number of beds. At C.S.S.D., management and rational maintenance of cleaning and sterilization machines, are being conducted in accordance with the situation.

2) As fit economic conditions, cleaning, sterilization and responsibilities could be allocated between C.S.S.D. and off-site sterilization service center to make it possible to plan and maintain the machines of simpler C.S.S.D.
\end{abstract}

Keywords: Off-Site Sterilization Service, Acute H ospital, Central Sterile Supply D epartment, Sterilization Service Center 院外洗浄滅菌システム, 急性期病院, 中央滅菌材料部, 洗浄滅菌センター

\section{1.はじめに}

現在、各都道府県は地域医療構想（ビジョン）を策定し、地域の 医療機能の分化・連携などの再編を促す取り組みを行っている。こ れにより、特に急性期病院では医療機能の特化や他の医療施設との 機能連携などを模索する場面が出現すると考えられ、その中で医療 を支援する機能においても更なる合理化を図ることが予想される。 筆者らは、これら機能を他の施設との相対的な関係において再編し、 その結果により急性期病院の建築計画を検討寸ることが、今後の重 要な視点になると考えた。

以上を踏まえ、本研究では急性期病院内において滅菌器材 (以下、 器材）の洗浄・滅菌業務を通じて医療を支援する機能を有する中央 滅菌材料部（以下、中材部）に着目した。いわゆる感染症新法の施 行（1999年）以降、感染管理の考え方が大きく変化し、洗浄・滅菌 装置（以下、装置等）の機能の向上などにより、中材部の運用や建 築計画の考え方は、大きく変化したと言われる。一方、中材部での 器材の洗浄・滅菌業務を外部業者に委託し、業務実施に伴う支出を 減少させて経営状況の向上を図る取り組みも進められている。さら に、病院外で器材の洗浄・滅菌業務を専門に実施する施設（以下、 院外滅菌C）を活用し、病院内の中材部における洗浄・滅菌業務内容 を限定・縮小寸る院外洗浄滅菌システム (以下、院外滅菌S) を導入
する病院事例が散見される。この動きは、前述の急性期病院におけ る医療機能の分化・連携のための一つの仕組みとしても位置づけら れる。

\section{2. 研究概要}

(1) 研究の目的と流れ

本研究では上記の背景に基づき、今後の中材部の計画手法の一つ として、院外滅菌Sを導入した急性期病院（以下、導入病院）の中材 部の運用や建築・装置等の整備状況を明らかにし、その特性を把握 することを目的とする。

具体的には、以下の流れで論をすすめる。

(1)導入病院の属性と中材部の運用 - 建築 - 装置等の概況を相対的に 明らかにする。

(2)導入病院事例の中材部の運用・建築・装置等の特性を把握する。

\section{(2) 研究の方法}

本研究では、アンケート調査、インタビュー・現地観察調查、文 献調查の結果を分析して考察する。表 1 に各調查の概要を示す。

まず、感染管理の新たな考え方を持ち合わせ、また物品管理の意 識が比較的高いと思われる、近年の 200 床以上の急性期病院を対象と

したアンケート調査を実施し、その結果より全国の急性期病院にお
$*$ 北海学園大学工学部建築学科 教授・博士 (芸術工学)

** 帝塚山大学現代生活学部居住空間デザイン学科 工博
Prof., Dept. of Architecture and Building Engineering, Faculty of Engineering, Hokkai-Gakuen University, Dr.Design

Dept. of Living Space Design, Faculty of Contemporary Human Life Science,

Tezukayama University, Dr.Eng. 
ける中材部の運用と建築・装置等の整備概況を把握すると共に、導 入病院の抽出を行った。次に、中材部で使用される装置等製造企業 および国内複数箇所に院外滅菌Cを運営している企業から、比較的院 外滅菌Cへの業務委託量が相対的に多いと思われる導入病院事例を 推薦してもらい、先のアンケート調查の結果より抽出した導入病院 の一部と共に、インタビュー・現地観察調查の対象とした。またこ れら調查の結果を踏まえて、文献調查も実施した。

以上のアンケート調査と文献調査の結果より、導入病院の属性とそ の中材部の運用・建築・装置等の概況を、院外滅菌Sを導入していな い病院 (以下、非導入病院) のそれらと比較して検討した。また、導 入病院事例の中材部の運用・建築・装置等の特性は、インタビュー・ 現地観察調査と文献調査の結果を用いて検討した。

\section{(3) 既存研究の状況}

これまでの我が国における中材部の建築計画に関する既存研究は、 以下のものが挙げられる。

古くは、田口の中材部の運用の実情を調查して計画上の特性を報

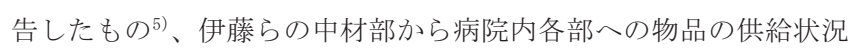
を述べたもの ${ }^{6)}$ 、池田と上田らの、中材部内の平面計画、面積、運 用、装置等、取り扱っている物品の状況を整理し、建築計画につい て考察したもの 7 10) がある。また中野は、機能と位置づけについて SPD部門の業務分析等を通じて述べる ${ }^{11)} と と も に 、 100$ 床以上の病院 の実態調査結果をもとに、中材部の機能範囲、全体計画からみた位 置づけ、配置計画、運用管理について概説し、平面計画の考え方と 設計試案を提示している ${ }^{12)}$ 。

近年の感染管理の考え方の変化を踏まえて論じたものは、中野の 感染対策を踏まえた作業の流れ、ゾーニング、平面計画について述

\section{表 1 各種調查の概要}

\begin{tabular}{|c|c|c|}
\hline \multirow[t]{5}{*}{$\begin{array}{l}\text { アンケート } \\
\text { 調査 }\end{array}$} & 調査手法： & 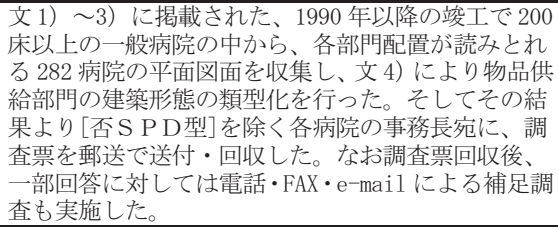 \\
\hline & 調査内容： & $\begin{array}{l}\text { 病院の属性、中材部の運用状況、装置等の整備状 } \\
\text { 況、構成諸室の使用状況など }\end{array}$ \\
\hline & 実施時期： & 2012 年 6 月～11月 \\
\hline & 対象施設数： & 174 病院 \\
\hline & 回答施設数： & 85 病院（回収率：48.9\%） \\
\hline \multirow{4}{*}{$\begin{array}{l}\text { インタビュー } \\
\text { •現地観察 } \\
\text { 調査 }\end{array}$} & 調査手法： & $\begin{array}{l}\text { 上記アンケート調査の結果を踏まえ、導入病院の } \\
\text { 中から立地を考慮して } 2 \text { 病院を、院外滅菌 C に委 } \\
\text { 託している滅菌方法を考慮して } 3 \text { 病院をそれぞれ } \\
\text { 抽出した。また装置等製造企業および国内複数箇 } \\
\text { 所で院外滅菌 C を運営している企業からの情報に } \\
\text { 基づいた導入病院 } 5 \text { 病院も加えた、計 } 10 \text { 病院の } \\
\text { 中材部の担当者と、こ病院より業務を受託し } \\
\text { ている一部院外滅菌Cの担当者に対してインタ } \\
\text { ビューを行うと共に、関連諸室内を観察した。 }\end{array}$ \\
\hline & 調査内容： & $\begin{array}{l}\text { 病院の属性、中材部の運用状況、器材の取扱いの } \\
\text { 状況、院外滅菌 S の導入状況、装置等備状況 } \\
\text { 、構成諸室の用状況など }\end{array}$ \\
\hline & 実施時期： & 2012 年 7 月 2015 年 3 月 \\
\hline & 対象施設数： & $\begin{array}{l}\text { 導入病院 : } 10 \text { 病院 (うち }[\mathrm{SI}] \text { の状況は業務を受託 } \\
\text { している院外滅菌 C 担当者より把握) } \\
\text { 院外滅菌 C }: 7 \text { 施設 } \\
\end{array}$ \\
\hline \multirow{3}{*}{ 文献調査 } & 調査手法・内容： & $\begin{array}{l}\text { アンケート調査結果及びインタビュー調査で収 } \\
\text { 集した病院平面図より、CAD ソフトウェア（エー } \\
\text { アンドェー社製 Vectorworks 2011）を用いて中材 } \\
\text { 部の面積などを計測した。 }\end{array}$ \\
\hline & 実施時期： & 2012 年 6 月 2015 年 3 月 \\
\hline & 対象施設数： & $\begin{array}{l}\text { アンケート調査回答施設 : } 85 \text { 病院 } \\
\text { インタビュー・現地観察調査対象導入病院 : 4病院* }\end{array}$ \\
\hline
\end{tabular}

ベた総説 ${ }^{13)}$ 、辻の感染管理基準の考えに沿った手術部、ICUと共に中 材部の平面計画について述べた総説 $\left.{ }^{14}\right)$ がある。この他、日本医療機 器学会が監修した資料 $\left.{ }^{15}\right)$ では、洗浄滅菌手法の原理と業務内容を述 べる中で、業務の外部委託の一環として院外滅菌Sを解説している。

以上のいずれの研究や資料においても、院外滅菌Sを導入した中材 部事例の実態把握を踏まえて建築計画を論考したものは見当たらず、 本研究は独自性及び有用性を有していると考えた。

\section{3. 導入病院の属性と中材部の運用・建築 - 装置等の概況}

アンケート調查の結果、導入病院は 19 病院 (回答施設数の $22.4 \%$ ) であった。これら病院の委託している滅菌方法別の内訳は、酸化工 チレンガス滅菌のみが 12 病院（導入病院の $63.2 \%$ ）と最も多く、 次いで高圧蒸気滅菌のみが 3 病院 (同 $15.8 \%$ )、高圧蒸気滅菌十酸 化エチレンガス滅菌が 3 病院（同 $15.8 \%$ )、高圧蒸気滅菌十酸化エ チレンガス滅菌十過酸化水素低温プラズマ滅菌が 1 病院 (同 5. 3\%) であった。以下、これら導入病院の属性と中材部の運用・建築・装 置等の概況を、非導入病院（66 病院）のそれらと比較検討し、相対 的に明らかにする。

\section{（1）病院の属性}

基本的な属性として病床数、竣工年、開設主体について、また急 性期病院の特性を示寸指標である平均在院日数と共に、器材の洗 浄・滅菌業務量と関係があると思われる年間手術件数について述べ る。表 2 にこれらの状況を示す。

導入病院の平均病床数は、413.2 床であった。病床規模別でみる と、中規模の事例が導入病院全体の $57.9 \%$ 、過半数以上を占めて いる。導入病院の竣工年は、2000 年以降の事例が導入病院全体の $73.7 \%$ と多数を占めている。導入病院の開設主体は、国公立が導入 病院全体の $47.4 \%$ 占めて最も多く、次いで公的とその他がそれぞ れ $21.2 \%$ 占めている。なお、その他の内訳は学校法人、財団法人、 民間企業などであった。導入病院の平均在院日数は 14.4 日、年間手 術件数は 3577.5 件/年で 100 床あたり 878.6 件/年であった。

表 2 導入病院/非導入病院の属性

\begin{tabular}{|c|c|c|c|c|c|}
\hline & \multirow{2}{*}{ 計 } & \multicolumn{3}{|c|}{ 病床規模 } \\
\hline & & & 小 (200〜299床) & 中 (300 599床) & 大 (600 床〜) \\
\hline \multirow{2}{*}{\multicolumn{2}{|c|}{ 合 計 }} & $19(100.0)$ & $5(100.0)$ & \begin{tabular}{|ll}
$11(100.0)$ \\
\end{tabular} & \begin{tabular}{|c|}
$3(100.0)$ \\
\end{tabular} \\
\hline & & $66(100.0)$ & $12(100.0)$ & $42(100.0)$ & $12(100.0)$ \\
\hline \multirow{8}{*}{$\begin{array}{l}\text { 䇋 } \\
\text { 年 }\end{array}$} & 1990～1994 年 & $\begin{array}{rr}3(15.8) \\
10(15.2\end{array}$ & $\begin{array}{l}0(0.0) \\
0\end{array}$ & $\begin{array}{l}3(27.3) \\
\end{array}$ & $\begin{array}{l}0(0.0) \\
0\end{array}$ \\
\hline & 1995 ح & $2(10.5)$ & $0(-0.0)$ & $1\left(\begin{array}{r}0.1) \\
-1\end{array}\right.$ & $1(-33.3)$ \\
\hline & & $22(33.3)$ & $7(58.3)$ & $12(28.6)$ & $3(25.0)$ \\
\hline & 2000 2004 年 & $\begin{array}{r}5(26.3) \\
19(28.8)\end{array}$ & $\begin{array}{ll}1 & (20.0) \\
2 & (16.7)\end{array}$ & $\begin{array}{rr}3 & (27.3) \\
13 & (31.0)\end{array}$ & $\begin{array}{l}33.3) \\
33.3)\end{array}$ \\
\hline & مי & $7(36.8)$ & $3(60.0)$ & $3(27.3)$ & $1(-33.3)$ \\
\hline & $2005 \sim 2009$ 年 & $14(21.2)$ & $0(0.0)$ & $11(26.2)$ & 25.0) \\
\hline & 2010 年〜 & $2(10.5)$ & $1(20.0)$ & $1(9.1)$ & $0.0)^{-1}$ \\
\hline & & $1(1.5)$ & $1(8.3)$ & $0(0.0)$ & $0(0.0)$ \\
\hline \multirow{6}{*}{$\begin{array}{l}\text { 閏 } \\
\text { 隹 }\end{array}$} & 国公立 & $9(47.4)$ & $1(20.0)$ & $7(63.6)$ & $1(33.3)$ \\
\hline & & $49(-4 \cdot 2)$ & $7(58.3)$ & $34(81.0)$ & $8(66.7)$ \\
\hline & 公的 & $9(136)$ & $3 \quad(250)$ & $5 \quad(119)$ & 33. 3) \\
\hline & |医療法人 & $(10.5)$ & $2(40.0)$ & $0(0.0)$ & $0.0)^{-}$ \\
\hline & & $3=(-4.5)$ & $\left.\begin{array}{l}1 \\
-2\end{array}-8=3\right)$ & $2(-4.8)$ & 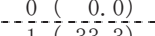 \\
\hline & その他 & $5\left(\begin{array}{r}4.1 \\
5\end{array}\right.$ & $1(8.3)$ & $1\left(\begin{array}{l}1.1 \\
1(2.4)\end{array}\right.$ & $3(25,0)$ \\
\hline \multirow{2}{*}{\multicolumn{2}{|c|}{$\begin{array}{c}\begin{array}{c}\text { 平均在院日数 } \\
(\text { 日) }\end{array} \\
\end{array}$}} & 14.4 & 17.4 & 13.3 & 13.5 \\
\hline & & 14.0 & 15.1 & 13.9 & 13.0 \\
\hline \multirow{2}{*}{\multicolumn{2}{|c|}{$\begin{array}{c}\text { 平均年間手術件数 } \\
\text { (件/年) }\end{array}$}} & 3577.5 & 2096.0 & 3553.9 & 6133.3 \\
\hline & & 3384.5 & 1088.7 & 3191.8 & 6354.6 \\
\hline
\end{tabular}
対する割合（\%）。表 3〜5 についても同様 
導入病院の 100 床あたりの平均病床数、平均在院日数、平均年間手 術件数について非導入病院のそれらと比較したところ、100 床あた りの年間手術件数について $5 \%$ 水準で有意差が認められた。つまり、 導入病院は非導入病院と比較して、病床規模によらず手術を相対的 に多く実施している様子が示唆された注1)。

\section{(2) 中材部の運用の概況}

院外滅菌 S の導入の主目的の 1 つとして院内（中材部）での業務 量の縮小がある。その結果、中材部での洗浄・滅菌業務の担当者人 数の減少や、稼働時間の短縮が実現する。またこの様な業務体制の 変更に対応寸るために、中材部での業務の外部委託業者への委託が 院外滅菌 S 導入の要件となっていることも考えられる。そこで中材 部の運用の概況として、業務担当者人数と、その担当者のうち外部 委託者が占める員数割合 (担当者の外部委託割合)、平日の稼働時間 について述べる。また器材の洗浄・滅菌業務の実態として、特に機 能上密接な関係がある手術部との関係を明らかにするために、取扱 い全器材量に占める手術部用器材量の相対的割合について述べる。

1）業務担当者の人数・外部委託割合注 2)

図 1 に導入病院/非導入病院別にみた病床数と担当者人数との関 係を示す。導入病院、非導入病院ともに $0.01 \sim 0.05$ 人/床に分布し ている。100 床あたりの人数をみると、導入病院は 2.3 人 $/ 100$ 床、 非導入病院は 2.2 人/100 床で、両者の間に有意差は認められなかった。

次に図 2 に、導入病院/非導入病院別にみた担当者の外部委託割合 を示す。導入病院、非導入病院ともに $100 \%$ の事例が最も多く、次 いで $0 \%$ が多い。この状況から、担当者の外部委託がかなり進んで いるか、または外部委託がほとんど進んでいないか、に大きく分か れていることが示された。

外部委託割合については、導入病院と非導入病院の各平均值の間 には有意差は認められなかった。

2）平日の稼働時間

図 3 に、導入病院/非導入病院別にみた平日の稼働時間の分布状況 を示す。導入病院、非導入病院ともに 480 599 分が最も多く、長時 間になるに従い事例数は減少している。

また、導入病院の平均稼働時間は 678.7 分、非導入病院は 603.3 分で、両者の間には $5 \%$ 水準で有意差が認められた。導入病院では、 後述のとおり手術部との機能上の関係が深いことから器材取扱い量 が多くなり、また手術部の運用時間にも影響されて、結果として稼 働時間が長時間となっていると考えられる。

3）取扱い全器材量に占める手術部用器材量の相対的割合

器材は主に手術部用、外来部用、病棟用に分けることができる。 ここでは特に、導入病院/非導入病院別にみた取扱い全器材量に占め る手術部用器材量の相対的割合の分布状況を図 4 に示す。その結果、 導入病院、非導入病院ともに 50〜 $74 \%$ が最も多く、中材部と手術部 との機能上の関係が、外来部や病棟との関係より相対的に深いこと が示唆された。

また、導入病院の平均相対的割合は $52.6 \%$ 、非導入病院は $45.9 \%$ であった。角変換を行った後に両者を比較したところ $5 \%$ 水準で有 意差が認められた。つまり、導入病院の中材部は非導入病院と比べ

て、手術部との機能上の関係がより深いことが示唆された。

（3）中材部の建築・装置等の整備概況

導入病院の中材部に求められる建築・装置等に関する要件に関し

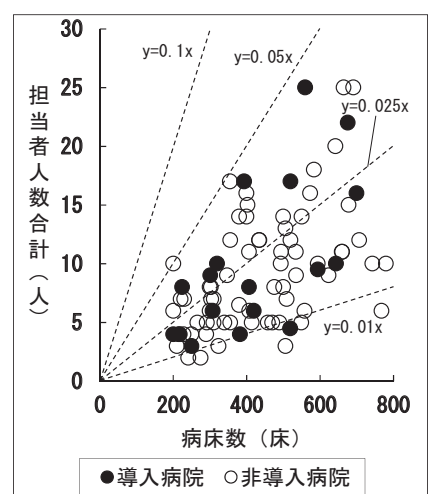

図 1 病床数と担当者人数 との関係

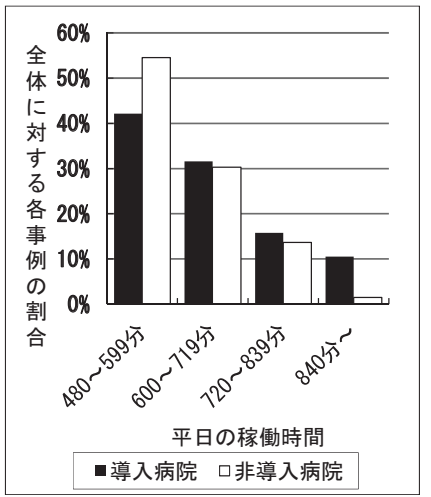

図 3 平日の稼働時間の分布

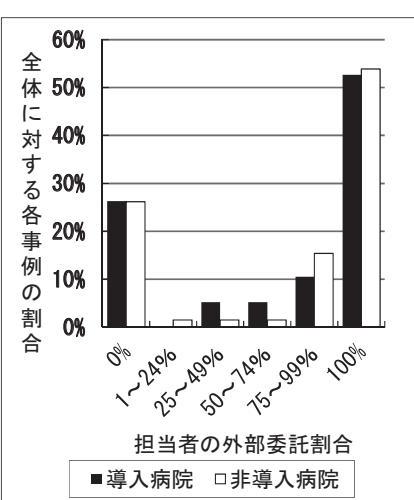

図 2 担当者の外部委託割合 の分布

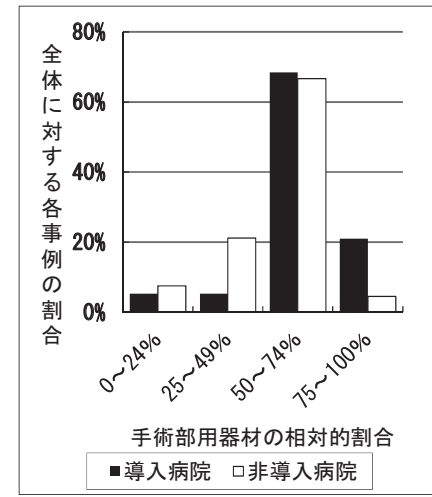

図 4 取扱い全器材量に占め 対的割合の分布 る手術部用器材量の相

て器材搬送の効率性の視点から中材部と手術部との位置関係、業務 の安全性の視点から中材部内の清污区分の考え方に基づくゾーニン グの状況、そして業務の経済性の視点から中材部の面積規模と各種 装置等の整備台数について述べる。

1）中材部と手術部との位置関係

表 3 に、導入病院/非導入病院別にみた中材部と手術部との位置関 係を示す。導入病院は、同一階で隣接している病院が導入病院全体 の $56.6 \%$ と最も多く、次いで上下階で隣接が $26.3 \%$ 、上下階で分離 が $21.1 \%$ 占めている。非導入病院は上下階で隣接している病院が 最も多い。

2）中材部内の清污区分の考え方に基づくゾーニングの状況

病院外にある滅菌 C と器材のやりとりを行うこともあり、導入病 院の中材部には特に感染管理の取り組みが求められる。そこで表 4 に、導入病院/非導入病院別にみた清污区分の考え方に基づくゾーニ ングの状況を示す。導入病院では全てのゾーンを区画している $[\mathrm{IV}]$ のタイプが導入病院全体の $42.1 \%$ と最も多く、次いで中間ゾーンと 清潔ゾーンを区画している $[\mathrm{III}]$ のタイプが $36.8 \%$ を占めている。

3）面積規模

図 5 に、導入病院/非導入病院別にみた病床数と中材部面積との関 係を示す。導入病院、非導入病院ともに $0.25 \sim 1 \mathrm{~m}^{2} /$ 床に分布してい る。導入病院の 100 床あたりの平均面積は $64.8 \mathrm{~m}^{2} / 100$ 床、非導入 病院は $69.4 \mathrm{~m}^{2} / 100$ 床であった。また導入病院の延床面積に対する 平均割合は $0.76 \%$ 、非導入病院は $0.84 \%$ であった。

4) 各種装置等の整備状況

院内での業務内容や業務量に、装置等を用いて経済的に対応して 
いる状況をみるために、まず表 5 に種類別にみた滅菌装置の設置状 況を示す。導入病院のうち $\mathrm{AC}+\mathrm{PS}$ を設置しているものが $73.7 \%$ と 多くを占めている。

図 6 に、導入病院/非導入病院別にみた代表的洗浄装置であるウ オッシャーディスインフェクター（以下、WD）の 100 床あたりの設 置台数の分布を、図 7〜9 に代表的滅菌装置であるオートクレーヴ (以下、AC) 、酸化エチレンガス滅菌装置（以下、EOG）、過酸化水素 低温プラズマ滅菌装置（以下、PS）の 100 床あたりの設置台数の分 布を各々示す。導入病院では、WDを0.40〜 0. 79 台/100 床、ACを 0.40 〜0.79 台/100 床設置している病院が比較的多い。また EOG は設置し ていない病院が最も多く、PSの設置台数のばらつきは大きい。

次に導入病院の各装置の 100 床あたりの平均設置台数と非導入病 院のそれらとの比較を行ったところ、WD と PS の各平均設置台数は 導入病院が $5 \%$ 水準で有意に多く、EOG の平均設置台数は $1 \%$ 水準で 有意に少ないことがそれぞれ認められた。なお ACの平均設置台数は 有意差が認められなかった。また種類別にみた滅菌装置の設置状況 と導入病院/非導入病院との関係について独立性の検定を行った結

\section{表 3 中材部と手術部との位置関係}

\begin{tabular}{|c|c|c|c|c|c|}
\hline & \multirow{2}{*}{\multicolumn{2}{|c|}{ 計 }} & \multicolumn{3}{|c|}{ 病床規模 } \\
\hline & & & 小 (200～299床) & 中 (300～599床) & 大 (600 床〜) \\
\hline \multirow{2}{*}{ 合＼cjkstart計 } & 19 & $(100.0)$ & $5(100.0)$ & $11(100.0)$ & $3(100.0)$ \\
\hline & 66 & $(100.0)$ & $12(100.0)$ & $42(100.0)$ & $12(100.0)$ \\
\hline \multirow{2}{*}{ 同一階で隣接 } & 10 & $(56.6)$ & $4(80.0)$ & $6(54.5)$ & $0(0.0)$ \\
\hline & 23 & $(34.8)$ & $8(66.7)$ & $15(35.7)$ & $0(0.0)$ \\
\hline \multirow{2}{*}{ 上下階で隣接※ } & & $(26.3)$ & $0(0.0)$ & $3(27.3)$ & $2(66.7)$ \\
\hline & 25 & $(37.9)$ & $1(8.3)$ & $16(38.1)$ & $8(66.7)$ \\
\hline \multirow{2}{*}{$\begin{array}{l}\text { 上下階で分離※ } \\
\text { (部門間をEV、D 等で直結) }\end{array}$} & & ( 21.1) & $1(20.0)$ & $2(18.2)$ & $1(33.3)$ \\
\hline & 17 & $(25.8)$ & $3(25.0)$ & $11(26.2)$ & $3(25.0)$ \\
\hline \multirow{2}{*}{ 同一階で分離 } & & $(0.0)$ & $0(0.0)$ & $0(0.0)$ & $0(0.0)$ \\
\hline & & $(1.5)$ & $0.0)$ & $0(0.0)$ & $1(8.3)$ \\
\hline
\end{tabular}

く※>「上下階で隣接」している事例は、中材部が手術部との機能上の関係を
重視しているが同一階には位置していない場合を想定。一方で、上下 階で分離」している事例は、中材部が手術部より他の物品供給部門との 機能上の関係を重視して、手術部から離れて他の物品供給部門がある階 （地下階など）に位置している場合を想定。

表 4 中材部内のゾーニングの状況

\begin{tabular}{|c|c|c|c|c|c|c|c|}
\hline \multirow{2}{*}{ タイプ * } & \multicolumn{2}{|c|}{ ゾーン間の区画 } & \multirow{2}{*}{\multicolumn{2}{|c|}{ 計 }} & \multicolumn{3}{|c|}{ 病床規模 } \\
\hline & SとN & NとC & & & 小(200～299床) & 中(300～599床) & 大 $(600$ 床〜) \\
\hline \multirow{2}{*}[\mathrm{I}]{} & & t & & $(0.0)$ & $0(0.0)$ & $0(0.0)$ & $0(0.0)$ \\
\hline & よし & よし & 1 & $(1.5)$ & $1(8.3)$ & $0.0)$ & $0(0.0)$ \\
\hline \multirow{2}{*}[\text{II}]{} & to & t大 & & $(21.1)$ & $2(40.0)$ & $0.0)$ & $2(66.7)$ \\
\hline & めり & なし & 3 & ( 4.5$)$ & $0(0.0)$ & $0(0.0)$ & $3(25.0)$ \\
\hline \multirow{2}{*}{ [III ] } & た & 支り & 7 & $(36.8)$ & $1(20.0)$ & $6(54.5)$ & $0 \quad(0.0)$ \\
\hline & & めり & 35 & $(53.0)$ & $8(66.7)$ & $24(57.1)$ & $3(25.0)$ \\
\hline \multirow{2}{*}[\mathrm{IV}]{} & あり & あり & 8 & $(42.1)$ & $2(40.0)$ & $5(45.5)$ & $1(33.3)$ \\
\hline & めV & めり & 27 & $(40.9)$ & $3(25.0)$ & $18(42.9)$ & $6(50.0)$ \\
\hline
\end{tabular}

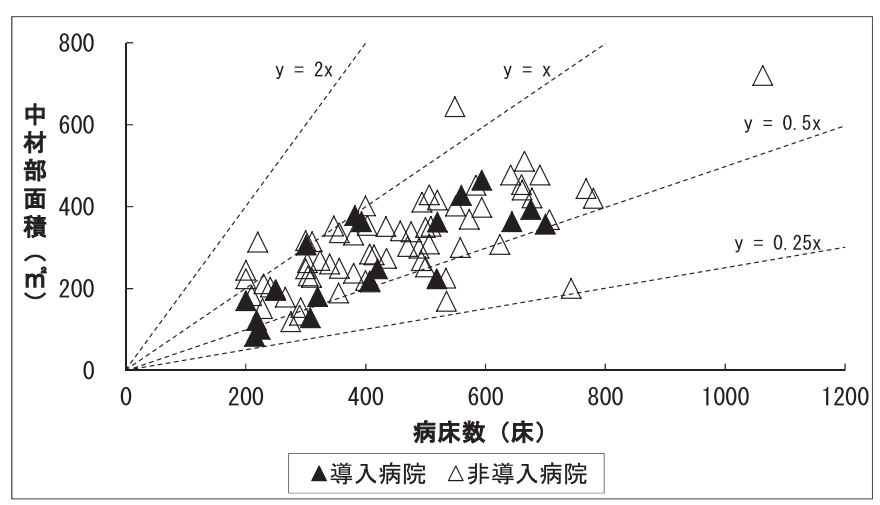

図 5 病床数と中材部面積との関係

果、有意な関係が認められた。これらより、非導入病院よりWDによ る洗浄業務量と院内での PS による滅菌業務量が相対的に多く注3)、 EOG による滅菌業務量は、院外滅菌 C に委託することで相対的に少 ないことが推察された。

\section{4. 導入病院事例における中材部の運用と建築・装置等の特性 (1) 調査対象病院と院外滅菌 C の概要}

表 6 に、インタビュー・現地観察調查対象病院の概要を示す。調 查対象病院のうち、[K I ] [ T K ] は都心部から離れた位置に立地し ている事例として、[GA] $[\mathrm{S} \mathrm{K}][\mathrm{T} \mathrm{S}]$ は、高圧蒸気滅菌＋酸化工 チレンガス滅菌対象器材または高圧蒸気滅菌十酸化エチレンガス滅 菌十過酸化水素低温プラズマ滅菌対象器材を院外滅菌 C に委託し、 その委託器材量が相対的に多いと思われる事例として、各々前述の アンケート調査の結果を踏まえて抽出した。また［T I ］［SＩ］［S $\mathrm{T}][\mathrm{S} \mathrm{S}][\mathrm{NK}$ ］は、装置等製造企業および国内複数箇所に院外滅菌 C を運営している企業からの情報に基づいて調査対象とした。

表 5 種類別にみた滅菌装置の設置状況

\begin{tabular}{|c|c|c|c|c|}
\hline & \multirow{2}{*}{ 計 } & \multicolumn{3}{|c|}{ 病床規模 } \\
\hline & & 小(200～299床) & 中 (300～599床) & 大 $(600$ 床〜) \\
\hline \multirow{2}{*}{ 合 計 } & $19(100.0)$ & $5(100.0)$ & $11(100.0)$ & $3(100.0)$ \\
\hline & $66(100.0)$ & $12(100.0)$ & $42(100.0)$ & $12(100.0)$ \\
\hline \multirow{2}{*}{$\mathrm{AC}+\mathrm{EOG}+\mathrm{P} \mathrm{S}$} & $2(10.5)$ & $1(20.0)$ & $1(9.1)$ & $0(0.0)$ \\
\hline & $48(72.7)$ & $7(58.3)$ & $31(73.8)$ & $10(83.3)$ \\
\hline \multirow{2}{*}{$\mathrm{AC}+\mathrm{EOG}$} & $3(15.8)$ & $1(20.0)$ & $1(9.1)$ & $1(33.3)$ \\
\hline & $15(22.7)$ & $4(33.3)$ & $9(21.4)$ & $2(16.7)$ \\
\hline \multirow{2}{*}{$\mathrm{AC}+\mathrm{PS}$} & $14(73.7)$ & $3(60.0)$ & $9(81.8)$ & $2(66.7)$ \\
\hline & $3(4.5)$ & $1(8.3)$ & $2(4.8)$ & $0(0.0)$ \\
\hline
\end{tabular}

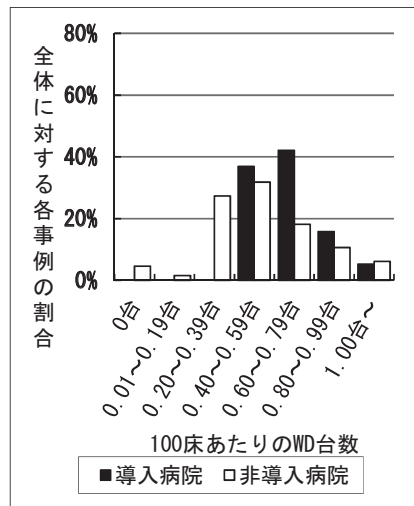

図 6100 床あたりのWD 設置 台数の分布

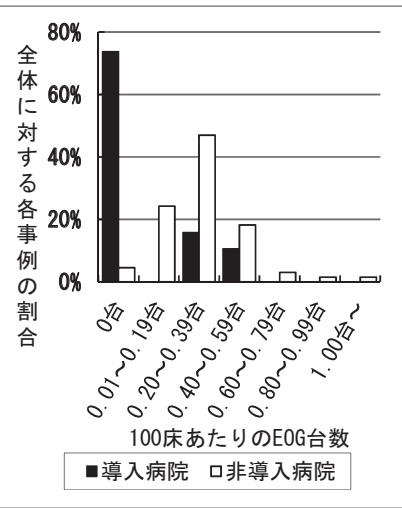

図 8100 床あたりのEOG 設置 台数の分布

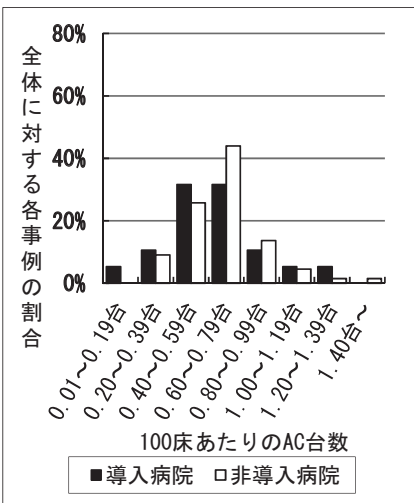

図 7100 床あたりの AC 設置 台数の分布

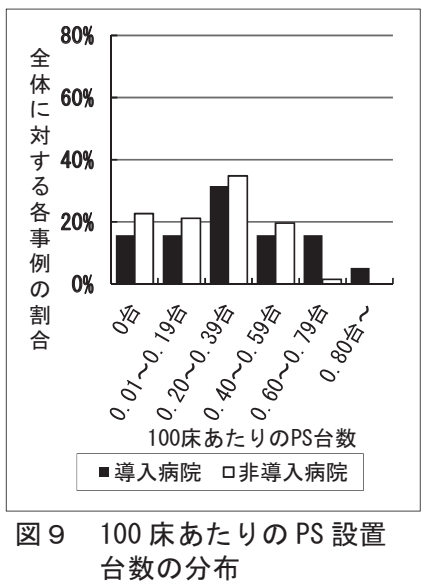


インタビュー・現地観察調査結果の分析対象とした病院概要

\begin{tabular}{|c|c|c|c|c|c|c|c|}
\hline 病院名 & 開設主体 & 病床数 & $\begin{array}{l}\text { 竣工・・ } \\
\text { 改修年 }\end{array}$ & \begin{tabular}{|c} 
院外滅菌 $S$ \\
導人年
\end{tabular} & 延床面積 & $\begin{array}{l}\text { 手術 } \\
\text { 室数 }\end{array}$ & $\begin{array}{c}\text { 年間手術 } \\
\text { 件数 }\end{array}$ \\
\hline$\left[\begin{array}{ll}\mathrm{T} & \mathrm{I}\end{array}\right.$ & その他 & 1,015 & $2010 * 1$ & 2006 & $72,396 * 2 \mathrm{~m}^{2}$ & 16室 & 10,000 件 \\
\hline$[\mathrm{GA}]$ & 財団法人 & 700 & $2013^{* 1}$ & 2005 & 77,604 & 20 & 7,480 \\
\hline$[\mathrm{K}$ I $]$ & 公立 & 649 & 2005 & 2005 & 67,396 & 10 & 5,166 \\
\hline$[\mathrm{S}$ I & その他 & $600 * 3$ & $2007^{* 3}$ & 2007 & $69,813^{* 3}$ & 16 & 7,759 \\
\hline$[\mathrm{T} \mathrm{S}$ & 公立 & 520 & 2003 & 2003 & 54,689 & 10 & 3,769 \\
\hline$[\mathrm{S} \mathrm{K}$ & 公的 & 519 & $2013^{* 1}$ & 2005 & 44,775 & 9 & 3,217 \\
\hline$[\mathrm{S} \mathrm{T}]$ & 財団法人 & 499 & 2000 & 2000 & 47,950 & 8 & 3,892 \\
\hline$[\mathrm{S} \mathrm{S}$ & 公的 & 400 & $2013^{* 1}$ & 2007 & 29,148 & 7 & 2,878 \\
\hline$[\mathrm{NK}]$ & 医療法人 & 261 & 2012 & 2012 & 16,358 & 4 & 500 \\
\hline$[\mathrm{T} \mathrm{K}]$ & 医療法人 & 218 & 2008 & 2005以前 & 19,124 & 4 & 2,302 \\
\hline
\end{tabular}

開設主体は公立、公的、医療法人、財団法人と様々である。また 病床数も約 $200 \sim 1000$ 床で規模が異なる。竣工・改修年は全て 2000 年以降である。院外滅菌 S は、改築時や中材部の大規模な改修時に 合わせて導入された場合が多いが、[T I ] [GA][S K ] [ S S ]では 導入後も装置等の入れ替えなどに伴う改修を行っている。年間手術 件数は、大部分の事例が年間 300 件/1 手術室以上であるが、 [N K $]$ のみが 125 件/ 1 手術室で相対的に少ない。この理由は、内科系疾患 の患者数が相対的に多く、回復期リハビリテーション病棟も有して いる $[\mathrm{N} \mathrm{K}]$ の医療機能上の特性によるものと考える。

次に、院外滅菌 S 成立には導入病院と院外滅菌 C の双方同時の運 営と建築・装置等の整備が不可欠であることも踏まえ、上記病院か ら業務を受託している院外滅菌 C の概要を表 7 に示す。 [ S I ] - C を 除き、全て民間企業が運営している。これら院外滅菌 C の業務を受 託している医療施設数は 12〜200 施設で、立地環境に関係なく自動 車で片道 120 分以内の範囲に位置している。一方 [S I ]-C は委託元 病院の直営であり、[S I ] を含めた系列 3 病院の業務のみを受託し ている。調查対象各病院との距離は、概衫自動車で 10 50 分弱の距 離に位置し、受託業務内容は、[T I ] [S I ] [ T S ] [S T ] [S S ] [ T $\mathrm{K}]$ からは洗浄・滅菌（洗浄、検査、組立・セッ卜組、包装、滅菌） 業務を受託し、[G A ] [ K I ] [ S K ] [N K ]からは滅菌（組立・セッ 卜組、包装、滅菌）業務を受託している。

\section{（2）院外滅菌 C の運営と建築・装置等の整備状況}

院外滅菌 C がどの様な運営や建築・装置等の整備をもって導入病 院からの業務を受託しているか、これを明らかにする為に、表 6 に 示した病院の滅菌業務委託先の院外滅菌 Cのうち協力が得られた一 部施設に対してインタビュー・現地観察調查を行った。表 8 に調查 対象施設を示す。

\section{1) 運営の状況}

運営曜日は、 $[S$ S ] - C を除き、平日に加えて土曜日または祭日も 運営を行っている。担当者は、 $[\mathrm{G} \mathrm{A}]-\mathrm{C}$ と $[\mathrm{S} \mathrm{T}]-\mathrm{C}$ を除き全ての施 設で看護職が配置されている。しかし何れの施設においても感染管 理看護師の有資格者は配置されていなかった。

施設機能について、器材の洗浄 ・滅菌の他に、器材の保管機能を 有している事例が見られた。例えば $[\mathrm{G} \mathrm{A}]-C 、[\mathrm{~T} \mathrm{I}]-C 、[\mathrm{~S} \mathrm{~T}]-C 、$ $[S \mathrm{~S}]-C$ では地域の学童検診で用いる器材を、検診を行う時期まで 保管している。また $[\mathrm{G} \mathrm{A}]-\mathrm{C} て ゙ は$ 病院で使用する滅菌済器材を保管 し、院外倉庫としての機能を有していた。図 10 にその様子を示す。 洗浄・滅菌業務においては、複数の施設からの器材を取り扱って いるため、その区分管理を行う必要がある。その場合、搬入された
表 7 業務を受託している院外滅菌 C の概要

\begin{tabular}{|c|c|c|c|c|c|c|}
\hline $\begin{array}{c}\text { 院外滅菌C } \\
\text { 名 } * 1\end{array}$ & $\begin{array}{l}\text { 運営 } \\
\text { 主体 }\end{array}$ & $\begin{array}{l}\text { 業務受 } \\
\text { 託医療 } \\
\text { 施設数 }\end{array}$ & \begin{tabular}{|l|} 
業務受 \\
託医療 \\
施設の \\
位置※2 \\
\end{tabular} & $\begin{array}{c}\text { 物品回収後に } \\
\text { 供給までに要する日数 }\end{array}$ & $\begin{array}{c}\text { 調査対象 } \\
\text { 病院から } \\
\text { の距離※3 }\end{array}$ & $\begin{array}{c}\text { 調査対象病院 } \\
\text { からの受託業 } \\
\text { 務内容 }\end{array}$ \\
\hline$-\mathrm{T} \mathrm{I}]-\mathrm{C}$ & 民間 & 50 & 90 & AC滅菌：1日, E0G滅菌：2日 & 28 & 洗浄＋滅菌 \\
\hline - G A ] $-\mathrm{C}$ & 民間 & 50 & 30 & AC滅菌：1日,E0G滅菌：2日 & 26 (高速) & 滅菌 \\
\hline K I ] $-\mathrm{C}$ & 民間 & 50 & 60 & AC滅菌：2日,E0G滅菌:2日 & 18 & 滅菌 \\
\hline $\mathrm{S} \mathrm{I}]-\mathrm{C}$ & {$[\mathrm{SI}]$} & 3 & 10 & AC減菌:1日,EOG減菌:2日,PS隇菌:0 1日 & 10 & 洗浄+滅菌 \\
\hline$-\mathrm{T} \mathrm{S}]-\mathrm{C}$ & 民間 & 12 & 120 & AC滅菌：1日,E0G滅菌：2日 & 17 & 洗浄+滅菌 \\
\hline $\mathrm{S} \mathrm{K}]-\mathrm{C}$ & 民間 & 200 & 60 & AC減菌:2日,EOG減菌:3日,PS滅菌:1 2日 & 20 & 滅菌 \\
\hline$[\mathrm{S} \mathrm{T}]-\mathrm{C}$ & 民間 & 100 & 120 & AC滅菌：1日,E0G滅菌：2日 & 12 & 洗浄+滅菌 \\
\hline$[\mathrm{S} \mathrm{S}]-\mathrm{C}$ & 民間 & 40 & 90 & AC滅菌:2日,E0G滅菌：3日 & 47 (高速) & 一部洗浄十滅菌 \\
\hline$[\mathrm{N} \mathrm{K}]-\mathrm{C}$ & 民間 & 34 & 90 & AC滅菌：2日, E0G滅菌：3日 & 16 (高速) & 滅菌 \\
\hline$[\mathrm{T} \mathrm{K}]-\mathrm{C}$ & \begin{tabular}{|l} 
民間 \\
\end{tabular} & 20 & 90 & AC滅菌：1日, E0G滅菌：2日 & 30 (高速) & 洗浄+滅菌 \\
\hline \multicolumn{7}{|c|}{ 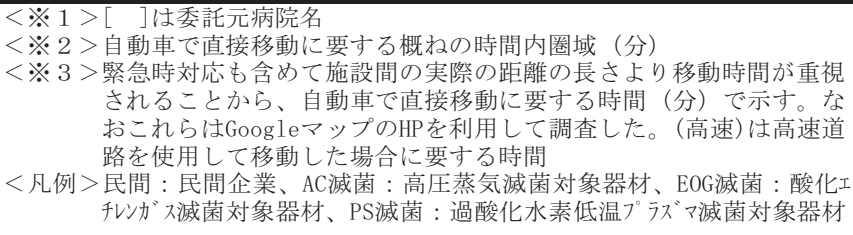 } \\
\hline
\end{tabular}

表 8 分析対象亡した院外滅菌 C の運営と建築・装置等

\begin{tabular}{|c|c|c|c|c|c|c|c|c|c|}
\hline \multirow{2}{*}{$\begin{array}{c}\text { 病院名 } \\
※ 1\end{array}$} & \multirow{2}{*}{$\begin{array}{l}\text { 稼働 } \\
\text { 開始 } \\
\text { 年 }\end{array}$} & \multirow{2}{*}{ 運営曜日 · 時間 } & \multirow{2}{*}{$\begin{array}{l}\text { 職種： } \\
\text { 職員数 }\end{array}$} & \multicolumn{2}{|c|}{ 建築の状況 } & \multicolumn{4}{|c|}{$\begin{array}{c}\text { 主な装置等の } \\
\text { 設置台数 }\end{array}$} \\
\hline & & & & $\begin{array}{c}\text { 延床面積 } \\
\left(\mathrm{m}^{2}\right)\end{array}$ & $\begin{array}{l}\text { 構造 } \\
/ \text { 階数 }\end{array}$ & WD & $\mathrm{AC}$ & EOG & PS \\
\hline$[\mathrm{SI}]-\mathrm{C}$ & 1997 & $\begin{array}{l}\text { 平 } 7: 30 \sim 19: 00 \\
\text { 祭 } 7: 30 \sim 19: 00\end{array}$ & $\begin{array}{r}\text { 常看: } 1 \\
\text { 常: } 32 \\
\text { 非: } 34 \\
\end{array}$ & 2,357 & $\begin{array}{l}\mathrm{RC}+\mathrm{S} \text { 造 } \\
/ \text { 地上 } 2 \text { 階 }\end{array}$ & 1 & 7 & 3 & 1 \\
\hline$[\mathrm{SK}]-\mathrm{C}$ & 1995 & $\begin{array}{l}\text { 平 } 9: 00 \sim 1 \\
\pm 9: 00 \sim 1\end{array}$ & $\begin{array}{l}\text { 常看: } 1 \\
\text { 常 : } 20 \\
\end{array}$ & 2,223 & \begin{tabular}{|c|}
$\mathrm{S}$ 造 \\
/地上2 階
\end{tabular} & 3 & 4 & 3 & 2 \\
\hline$[\mathrm{GA}]-\mathrm{C}$ & 2002 & $\begin{array}{l}\text { 平 9: } \\
\text { 土 9: }\end{array}$ & $\begin{array}{l}\text { 常: } 4 \\
\text { 非: } 30 \\
\end{array}$ & 993 & $\begin{array}{c}\mathrm{S} \text { 造 } \\
/ \text { 地上2階 }\end{array}$ & 1 & 3 & 2 & 0 \\
\hline$[\mathrm{TI}]-\mathrm{C}$ & 2005 & $\begin{array}{l}\text { 平 } 8: 30 \sim 17: 30 \\
\text { 土 } 9: 00 \sim 14: 00\end{array}$ & $\begin{array}{l}\text { 常看: } 1 \\
\text { 常: } 12 \\
\text { 非: } 2\end{array}$ & 979 & $\begin{array}{c}S \text { 造 } \\
/ \text { 地上2階 }\end{array}$ & 1 & 3 & 2 & 0 \\
\hline$[\mathrm{ST}]-\mathrm{C}$ & 2012 & $\begin{array}{l}\text { 平 } 7: 00 \sim 20: 00 \\
\text { 土 } 7: 00 \sim 18: 30\end{array}$ & 常: 34 & 821 & $\begin{array}{c}\mathrm{S} \text { 造 } \\
\text { /平屋 }\end{array}$ & 3 & 3 & 2 & 0 \\
\hline$[\mathrm{KI}]-\mathrm{C}$ & 1991 & $\begin{array}{l}\text { 平 } 8: 00 \sim 16: 30 \\
\text { 祭 } 8: 00 \sim 16: 30\end{array}$ & $\begin{array}{l}\text { 常准: } 1 \\
\text { 常臨: } 1 \\
\text { 常: } 5 \text {, 非: } 1\end{array}$ & 687 & $\begin{array}{c}S \text { 造 } \\
/ \text { 地上 } 2 \text { 階 }\end{array}$ & 0 & 2 & $3 * 2$ & 0 \\
\hline$[\mathrm{SS}]-\mathrm{C}$ & 2004 & 平 $8: 30 \sim 17: 15$ & $\begin{array}{c}\text { 常: } 12 \\
\text { 非看: } 1\end{array}$ & 511 & $\begin{array}{l}\mathrm{S} \text { 造 } \\
\text { /平屋 }\end{array}$ & 1 & 2 & 2 & 0 \\
\hline$※ 1$ & $\begin{array}{l}\text { 常看 } \\
\text { 常 : } \\
\text { WD : }\end{array}$ & 委託元病院名 & ※2>うち & 台け & $\begin{array}{l}\text { 攺障中で } \\
\text { 祭日 }\end{array}$ & & & & \\
\hline
\end{tabular}

器材を、医療施設名が記された金属製の札と共にカゴに入れて管理 したり、医療施設ごとに作業担当者や作業時間を固定、作業場所を 区分、などの運用上の工夫により、器材の混在を防止している。

また、災害時に院外滅菌 C 自体が被災して機能が停止したり、院 外滅菌 C と医療施設間の物流が滞った場合、洗浄・滅菌業務を委託 している医療施設の機能が停止または縮小寸る可能性がある。その 場合、他の系列施設から滅菌済器材を融通するなどの対策を計画し、 委託元医療施設の事業の継続性を担保する取り組みを行っている。

2）建築の整備状況

延床面積は、約 500〜 2, $400 \mathrm{~m}^{2}$ に分布し、構造・階数は S 造で平屋 または地上 2 階建であった。建築基準法では「工場」として位置付 けられる注4)。図 11 にその外観例を示す。

洗浄・滅菌業務を行う洗浄室、組立室、既滅菌室以外に、器材の 搬出入を行う出入口が洗浄室や既滅菌室に前室を介して隣接する平 面計画は、全ての事例で共通している。その他、事務室、会議室、 更衣室、倉庫、機械室などで全体が構成され、上記の器材搬出入機 能以外は、医療施設における中材部の建築計画の考え方と大きな差 


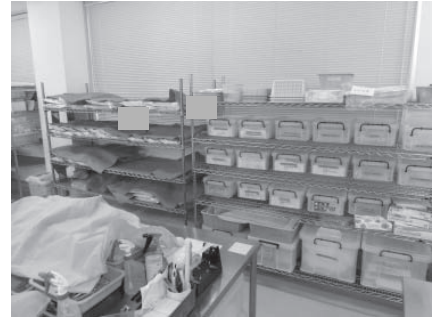

図 10 医療施設の滅菌済器材 を保管している様子

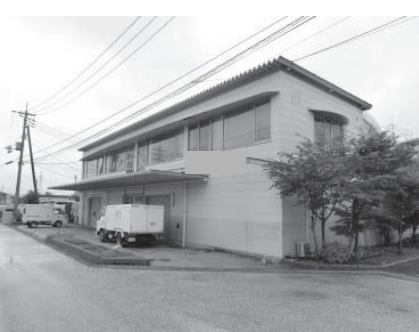

図 11 院外滅菌 C の外観例
異はないと考えた。

3）装置等の整備状況

設置されている主な装置等の種類は、医療施設の中材部に整備さ れているそれらと大きな差違は見られない。しかし一定量以上の器 材を取り扱う関係で、大容量の装置がその中心であった。

また前章でその傾向が示されたとおり、酸化エチレンガス滅菌器 材の受入れの増加注 5$)$ に伴い、何れの事例でも EOG を複数台設置して いる。また PS は面積規模が相対的に大きい [S I ]-C と [S K ]-C に は設置されていたが、それ以外の施設には設置されていなかった。

\section{（3）中材部および T. S. S. U. 注 6) の有無と業務}

近年の病院内における器材の洗浄・滅菌業務は、感染管理の観点 から中央化が進められ、滅菌材料部が「中央」滅菌材料部と呼ばれ るようになった。しかし今回の調查結果から、院外滅菌Ｓの導入に よりこれに当てはまらない事例が見られた。

まず [S I ] は、原則総ての器材の洗浄 ・滅菌業務を同一敷地内に ある院外滅菌 C が行い、中材部を有していない。そして T.S. S. U. で 臨時・緊急・夜間の洗浄・滅菌業務のみを現場判断で行っている。 これは、[S I ]-C が [S I ]の他の系列病院の敷地内に配置され、上 記のとおり経営主体が [S I ] を含めた系列 3 病院と同一主体である ことから、敷地内別棟で洗浄・滅菌業務を行っている施設として位 置づけられていることによる。

また $[\mathrm{S} \mathrm{K}]$ は、中材部で全ての器材の滅菌・洗浄業務を行ってい たが、院外滅菌 S の導入に際して中材部とその周辺部門の改修を行 うと共に、面積の関係上 T. S. S. U. を新たに設置し、そこで手術部で 使用した器材の洗浄・組立・セッ卜組・包装を行うようになった。

いずれも、院外滅菌 S の導入が院内の洗浄・滅菌業務の中央化に 影響を及ぼした事例であり、従来とは異なる院外滅菌 C の機能を重 視した考え方で計画・設計が進められたと言える。

\section{（4）中材部の運用之建築・装置等の整備状況}

表 9 に、中材部を有さない [S I ] を除く各調查対象病院の中材部 の運用と建築・装置等の整備状況を示す。

1）運用の状況

運用曜日は、 $[\mathrm{G} \mathrm{A}][\mathrm{S} \mathrm{K}][\mathrm{S} \mathrm{T}][\mathrm{S} \mathrm{S}][\mathrm{N} \mathrm{K}]$ は平日のみの運用 を行い、それ以外の事例は土曜日や日曜日も運用を行っている。運 営方式は、 $[\mathrm{T} \mathrm{K}]$ は病院直営、 $[\mathrm{N} \mathrm{K}]$ は直営十外部委託であり、そ れ以外の事例は外部委託である。また $[\mathrm{K} \mathrm{I}]$ は [K I ]-Cの運営業者 とは異なる業者に業務を委託している。 $[\mathrm{S} \mathrm{K}]$ では、院外滅菌 C を 経営している同一業者が、院内での器材の洗浄から包装までの一連 の業務も受託している。なお器材の院外一の持ち出し時には一次処 理済みであることが条件であるが、院内での洗浄業務も院外滅菌 C を運営している同一業者が受託した場合は、この業者により器材の
表 9 各病院の中材部の運用と建築・装置等の整備状況

\begin{tabular}{|c|c|c|c|c|c|c|c|}
\hline \multirow[b]{2}{*}{$\begin{array}{c}\text { 病院 } \\
\text { 名 }\end{array}$} & \multirow[b]{2}{*}{ 運用曜日・時間 } & \multirow[b]{2}{*}{$\begin{array}{l}\text { 職種 : } \\
\text { 職員数 }\end{array}$} & \multirow[b]{2}{*}{$\begin{array}{l}\text { 運営 } \\
\text { 方式 }\end{array}$} & \multirow{2}{*}{\multicolumn{2}{|c|}{\begin{tabular}{|c:c} 
建築の整備状況 \\
中材 & 面積※1, \\
$/ 0 \mathrm{P}$ 部 & (1床に対 \\
設置階 & 寸る面積) \\
\end{tabular}}} & \multicolumn{2}{|c|}{ 装置等の整備状況 } \\
\hline & & & & & & WD台数 & $\begin{array}{l}\text { 滅菌装置 } \\
\text { 台数*2 }\end{array}$ \\
\hline [TI $]$ & $\begin{array}{l}\text { 平 } 7: 00 \sim 22: 00 \\
\text { 土 } 7: 00 \sim 16: 00\end{array}$ & $\begin{array}{l}\text { 外 : } 30 \text { 人 } \\
\text { (0P部兼) }\end{array}$ & $\begin{array}{l}\text { 外委 } \\
\text { (同) }\end{array}$ & $\begin{array}{l}\text { 4階 } \\
/ 3 \text { 階 }\end{array}$ & $\begin{array}{l}857.6 \rightarrow \\
363.4 \mathrm{~m}^{2} \\
\left(0.36 \mathrm{~m}^{2}\right)\end{array}$ & 3 台 & $\begin{array}{l}\mathrm{AC}: 6 \rightarrow 3 \text { 台 } \\
\mathrm{EOG}: 2 \rightarrow 2 \text { 台 } \\
\mathrm{PS}: 0 \rightarrow 3 \text { 台 }\end{array}$ \\
\hline$[\mathrm{GA}]$ & $\begin{array}{l}\text { 平 } 8: 00 \sim 8: 00 \\
\text { (24時間) }\end{array}$ & $\begin{array}{l}\text { 外: } 18 \\
+(\text { 欠 } 1)\end{array}$ & $\begin{array}{l}\text { 外委 } \\
\text { (同) }\end{array}$ & $4 / 3$ & $\begin{array}{l}356.5 \\
(0.51)\end{array}$ & $1 \rightarrow 4$ & $\begin{array}{l}\mathrm{AC}: 2 \rightarrow 3 \\
\mathrm{EOG}: 0 \\
\mathrm{PS}: 1\end{array}$ \\
\hline [KI] & $\begin{array}{l}\text { 平 } 7: 30 \sim 21: 00 \\
\text { 土 } 8: 30 \sim 17: 30 \\
\text { 日 } 8: 30 \sim 17: 30\end{array}$ & 外: 15〜16 & $\begin{array}{l}\text { 外委 } \\
\text { (異) }\end{array}$ & $2 / 3$ & $\begin{array}{l}393.0 \\
(0.61)\end{array}$ & 3 & $\begin{array}{l}A C: 3 \\
E O G: 0 \\
P S: 2\end{array}$ \\
\hline [TS] & $\begin{array}{l}\text { 平 } 8: 30 \sim 20: 00 \\
\text { 土 } 8: 30 \sim 17: 00 \\
\text { 日 } 8: 30 \sim 17: 00\end{array}$ & $\begin{array}{l}\text { 看 : } 1 \\
\text { 外: } 15\end{array}$ & $\begin{array}{l}\text { 外委 } \\
\text { (同) }\end{array}$ & $2 / 3$ & $\begin{array}{l}362.1 \\
(0.70)\end{array}$ & 3 & $\begin{array}{l}\mathrm{AC}: 2 \\
\mathrm{EOG}: 0 \\
\mathrm{PS}: 1\end{array}$ \\
\hline [SK] & 平 $8: 30 \sim 17: 30$ & 外: 4.5 & $\begin{array}{l}\text { 外委 } \\
\text { (同) }\end{array}$ & $\mathrm{B} 1 / 3$ & $\begin{array}{c}342.3 \rightarrow \\
223.6 \\
(0.43)\end{array}$ & 3 & $\begin{array}{l}\text { AC }: 3 \rightarrow 1 \\
\text { EOG: } 1 \rightarrow 0 \\
P S: 0 \rightarrow 1\end{array}$ \\
\hline [ST] & 平 $8: 30 \sim 20: 00$ & $\begin{array}{l}\text { 外: } 5 \\
+ \text { (欠 } 2)\end{array}$ & $\begin{array}{l}\text { 外委 } \\
\text { (同) }\end{array}$ & $4 / 3$ & $\begin{array}{l}237.3 \\
(0.48)\end{array}$ & 1 & $\begin{array}{l}A C: 2 \\
E O G: 2 \\
P S: 1\end{array}$ \\
\hline [SS] & 平 $8: 30 \sim 17: 15$ & 外: 4 & $\begin{array}{r}\text { 外委 } \\
\text { (同) }\end{array}$ & $3 / 3$ & $\begin{array}{l}248.8 \\
(0.62)\end{array}$ & $\begin{array}{l:}1 \rightarrow 1 \\
(\text { 大型化) }\end{array}$ & $\begin{array}{l}\mathrm{AC}: 2 \rightarrow 3 \\
\mathrm{EOG}: 0 \rightarrow 1 \\
\mathrm{PS}: 1 \rightarrow 0\end{array}$ \\
\hline$[\mathrm{NK}]$ & 平 $8: 30 \sim 17: 00$ & $\begin{array}{l}\text { 看: } 2 \\
\text { 外: } 3\end{array}$ & $\begin{array}{l}\text { 直営+ } \\
\text { 外委 } \\
(\text { 同 }) \\
\end{array}$ & $3 / 3$ & $\begin{array}{l}125.8 \\
(0.48)\end{array}$ & 1 & $\begin{array}{l}\mathrm{AC}: 1 \\
\mathrm{EOG}: 0 \\
\mathrm{PS}: 1\end{array}$ \\
\hline [TK] & $\begin{array}{l}\text { 平 } 8: 30 \sim 17: 00 \\
\text { 土 } 8: 30 \sim 12: 30\end{array}$ & $\begin{array}{l}\text { 看: } 0 \sim 1 \\
\text { 技: } 0 \sim 1 \\
\text { 病: } 3 \\
\end{array}$ & 直営 & $1 / 1$ & $\begin{array}{l}122.1 \\
(0.56)\end{array}$ & 1 & $\begin{array}{l}\mathrm{AC}: 1 \\
\mathrm{EOG}: 1 \\
\mathrm{PS}: 1 \\
\end{array}$ \\
\hline
\end{tabular}

$<※ 1>$ VectorWorks2011を用いて中材部平面図より算出。

$<※ 2>\Gamma \rightarrow 」$ がある事例は(改修前) $\rightarrow$ (最新の改修後) の変化を示す

$<$ 凡例 $>$ 平：平日、土：土曜日、日：日曜日

外 : 外部委託職員、看 : 看護師、技 : 臨床工学技士、病 : 病院職員 外委 (同) : 院外滅菌 C運営企業と同一の業者に委託、外委 (委) : 院外 滅菌C運営企業とは異なる業者に委託

WD : ウオッシャーデイイイイフェタター、AC : オートクレーヴ、EOG : 酸化エチレカガス滅菌装置、

PS : 過酸化水素低温プラズマ滅菌装置

洗浄・滅菌管理や品質が保証され、院外滅菌 C 内に搬入後の器材の 取扱いを効率的に行うことが可能となる主7)。

業務に従事している職種は前述のとおり委託業者の他に、看護師 が管理者として担当している事例があった。その他に $[\mathrm{T} \mathrm{K}]$ では、 臨床工学技士も業務を担当している。これは、医療サービス提供に 関わるモノを管理する専門職種として臨床工学技士が適切であると の病院側の判断によるものである。

2）建築の整備状況

病院内で器材のやりとりを行う量が相対的に最も多いと考えられ る手術部との位置関係をみると、病床規模が相対的に小さい $[\mathrm{S}$ $\mathrm{S}][\mathrm{NK}][\mathrm{T} \mathrm{K}]$ は手術部に隣接して同一階に配置され、それ以外の 事例は手術部とは異なる階で垂直方向に重なる位置に配置されてい た。1 床あたりの面積は 0.36〜0.70 $\mathrm{m}^{2} /$ 床で、 [ T I ] [ S K ] は院外 滅菌 S 導入に伴う中材部の改修の際に、面積を減少させている。

3）装置等の整備状況

面積と同様に $[\mathrm{T}$ I $][\mathrm{S} \mathrm{K}$ ]では、院外滅菌 S の導入時に AC 及び PS を減少させて、整備や運用に要する経費を削減している。逆に $[G$ A]では、改築当初は高圧蒸気滅菌対象器材と酸化エチレンガス滅菌 対象器材の滅菌を院外滅菌 C 几委託していたが、委託費用と院内で の業務実施に要する費用を比較検討し、院外滅菌 C への委託内容を 見直して酸化エチレンガス滅菌対象器材の滅菌のみを委託すること に変更した。これに伴い中材部の改修時に $\mathrm{AC} の$ 台数を 1 台増加させ、 WD も連槽式 1 台から単槽式 4 台へ換装させている。また $[\mathrm{S} \mathrm{S}]$ でも 院外滅菌 S の導入に合わせて院内の洗浄・滅菌業務の中央化を図り、 装置等の種類や台数が変化している。 


\section{（5）院外滅菌 C へ洗浄・滅菌を委託している器材の内容}

院外滅菌 S の導入時に、院外滅菌 C に洗浄・滅菌を委託する器材 の種類や量などの内容が検討されるが、これは中材部の建築・装置 等の整備要件に大きく関わる。そこで表 10 にそれら器材の内容を示す。

器材の種類について、滅菌手法別にみると前章で述べたとおり、 酸化エチレンガス滅菌対象器材が主である。これは 1 回の滅菌に要 する時間が長時間であることや、酸化エチレンガス自体に毒性があ り装置の運用や管理に難があることが理由であった。また高圧蒸気 滅菌対象器材の一部を委託対象としている事例があった。対象は セット数の多い器材であり、万が一院外滅菌 C での洗浄・滅菌が計 画どおり行われなくてもある程度代替が利くという理由である。次 に器材の相対的な量は、病床規模とは関係なく、事例毎の委託内容 により異なっている。また量が少ない事例は、酸化エチレンガス滅 菌対象器材のみ又はそれが主な委託対象であることも特徴といえる。

事例ごとにみると、[S I ] は院内で使用している器材量の全て、 [S S ] は同じく約 $85 \%$ 、[S K] は約 $80 \%$ 強となり、相対的に多量の 器材が委託対象となっている。特に $[\mathrm{S} \mathrm{S}]$ は外来部・病棟用器材だ けではなく手術セット器材も対象としている。院外滅菌 S の導入時 に、手術セットの内容を見直して器材の種類を絞り込み、委託が可 能となる様にセット数を増やしたとのことであった。一方で、 [K I ] は数\%、[T S ] は 7\%、[G A ] は 10〜20\%である。[G A ] は前述の とおり委託器材量が減少し、[T S ] も委託費用を検討して高圧蒸気 滅菌対象器材量を縮小させているとのことであった。器材の使用部 門別でみると、 $[\mathrm{S} \mathrm{T}]$ は外来部・病棟用器材の全て、 $[\mathrm{N} \mathrm{K}]$ はそれ らの約 95\%、[T K]はそれらの 90\%を委託対象としている。外来 部・病棟用器材はセット数が多い為、前述の理由により委託対象と していると考える。一方、手術部用器材は、相対的に単価が高いこ とや一点物が多く、破損・紛失時の対応や、洗浄・滅菌が計画どお り行われない場合は代替が利きにくいなどの理由で、対象外となっ

\section{表 10 院外滅菌 C 人洗浄・滅菌を委託している器材の内容}

\begin{tabular}{|c|c|c|c|}
\hline \multirow[b]{2}{*}{ 病院 } & \multirow[b]{2}{*}{$\begin{array}{l}\text { 滅菌器材 } \\
\text { 使用部門 }\end{array}$} & 滅菌器材の種類 & \multirow[b]{2}{*}{ 委託している滅菌器材量の相対的割合 } \\
\hline & & $\begin{array}{|c:c:c|}A C & E O G: P S \\
\text { 滅菌!滅菌!滅菌 } \\
\end{array}$ & \\
\hline \multirow{2}{*}{ [TI $]$} & & $x: \times: x$ & \multirow{2}{*}{ 病棟及び外来部で使用している器材量の約 $67 \%$} \\
\hline & 外来部 & $\triangle x^{\triangle} \times$ & \\
\hline \multirow{2}{*}[\mathrm{GA}]{} & & $\begin{array}{l:l:l}x & 0 & x \\
\end{array}$ & \multirow{2}{*}{ 院内で使用している全器材量の約 10〜20\% } \\
\hline & 外来部 & $x: 0: x$ & \\
\hline \multirow{2}{*}{ [KI] } & 手行 & $\begin{array}{l:l:l}x & 0 & \times \\
\end{array}$ & \multirow{2}{*}{ 院内で使用している全器材量の数％ } \\
\hline & 外来部 & $\begin{array}{l:l:l}x & 0 & \times \\
\end{array}$ & \\
\hline \multirow{2}{*}{ [SI] } & 手術部 & $0: 0: 0$ & \multirow{2}{*}{ 院内で使用している全器材量のほぼ 100\% } \\
\hline & 外来部・病棟 & $0: 0: 0$ & \\
\hline \multirow{2}{*}{ [TS $]$} & 手術部 & $\begin{array}{c:l:l} & 0 & \times \\
\end{array}$ & \multirow{2}{*}{$\begin{array}{l}\text { 手術部で使用している器材量の5\% } \\
\text { +病棟及び外来部で使用している器材量の } 10 \% \\
\text { (院内で使用している全器材量の } 7 \% \text { ) }\end{array}$} \\
\hline & 外来部・病棟 & $\begin{array}{l:l:l}\triangle & 0 & \times \\
\end{array}$ & \\
\hline \multirow{2}{*}{ [SK] } & 手術部 & $\triangle: \bigcirc$ & \multirow{2}{*}{ 院内で使用している全器材量の約 $80 \%$ 強 } \\
\hline & 外来部・病棟 & $\triangle: O: \triangle$ & \\
\hline \multirow{2}{*}{ [ST $]$} & 手術部 & $x: x: x$ & \multirow{2}{*}{$\begin{array}{c}\text { 病棟及び外来部で使用している滅菌器材の全て } \\
\text { (院内で使用している全器材量の約 } 20 \%)\end{array}$} \\
\hline & 外来部・病棟 & $0: 0: x$ & \\
\hline \multirow{2}{*}[\mathrm{SS}]{} & 手術部 & $\triangle: \triangle: \times$ & \multirow{2}{*}{$\begin{array}{l}\text { 手術部で使用している器材量の約 } 50 \% \\
\text { 十病棟及び外来部で使用している器材量の99\% } \\
\text { (院内で使用している全器材量の約 85\%) }\end{array}$} \\
\hline & 外来部・病棟 & $0: 0: x$ & \\
\hline \multirow{2}{*}{ [NK] } & 手術部 & $x: 0: x$ & \multirow{2}{*}{$\begin{array}{l}\text { 手術部で使用している器忉量の約 } 10 \% \\
\text { ）病棟及び外来部で使用している器材量の約 } 95 \% \\
\text { (院内で使用している全器材量の } 36 \sim 40 \% \text { ) }\end{array}$} \\
\hline & 外来部・病棟 & $\triangle: O: \times$ & \\
\hline \multirow{2}{*}[\mathrm{TK}]{} & 手術部 & $\begin{array}{l:l:l}x & x & x \\
\end{array}$ & \multirow{2}{*}{$\begin{array}{l}\text { 病棟及び外来部で使用している器材量の } 90 \% \\
\text { (院内で使用している全器材量の } 45 \%)\end{array}$} \\
\hline & 外来部·病棟 & $\triangle: \times: x$ & \\
\hline
\end{tabular}

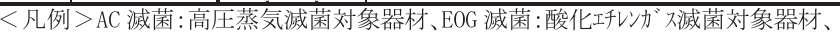
PS 滅菌: 過酸化水素低温プラズマ滅菌対象器材

$\bigcirc$ : 全て委託、 $\triangle$ : 一部委託、X: 委託していない
ている場合が多い。

\section{（6）洗浄・滅菌業務の実施場所}

器材の洗浄・滅菌時は、各業務工程の内容と流れに応じた関連部 門や部屋の配置、また院外滅菌 Cへの器材の受け渡し方法や場所の 検討・計画が必要となる。そこで表 11 に、院内外における洗浄・滅 菌業務の実施場所を示寸。［S I ］［ＳＴ］を除いた全事例では、同一 部門で使用している器材であっても、種類により全て院内で洗浄・ 滅菌を行うものと、途中の工程から院外滅菌 C で行うものに分かれる。

事例ごとにみると、 [ T I ] [ T S ] [ S T ] [ S S ] [ T K ]では、外来 部や病棟で使用した（一部の）器材は一次処理のみを行った後に、

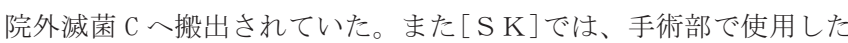
器材は T. S. S. U. で、外来部や病棟で使用した器材は中材部で各々洗 浄・組立・セッ卜組・包装後に院外滅菌 C 一一部搬出されており、 他の事例とは異なる特徵的な工程である。

\section{（7）特徵的な中材部事例の平面計画}

ここでは導入病院における中材部の建築空間の質的な特性を把握 することを目的として、院外滅菌 S 導入を前提とした中材部の計 画・設計が行われた事例と、院外滅菌 S 導入之同時期に中材部の改 修を行った事例の平面計画の状況を検討寸る。図 12 に院外滅菌 S 導入を前提として計画・設計が行われた $[\mathrm{N} \mathrm{K}]$ における中材部の平 面図を示し、図 13 に $[\mathrm{S} \mathrm{K}]$ における改修前後の中材部および周辺の 平面計画の変化を示す。

$[\mathrm{N} \mathrm{K}]$ では、院外滅菌 C との間で器材を搬出入させる為の専用動 線を確保している。院内で使用された器材は洗浄室に集約された後、 WD などで洗浄を行った後に組立室へ移される。ここから前室を介し て院外滅菌 C 一器材が搬出され、また滅菌済器材が搬入されている。 なお $[\mathrm{N} \mathrm{K}]$ 以外の事例でも器材（十搬送者）の動線や搬出前の一時 保管場所が確保され、器材の受け渡し時は院内の業務担当者と院外

表 11 院内外における洗浄・滅菌業務の実施場所

\begin{tabular}{|c|c|c|c|c|c|c|}
\hline \multirow{2}{*}{$\begin{array}{c}\text { 病院 } \\
\text { 名 }\end{array}$} & \multirow{2}{*}{$\begin{array}{l}\text { 滅菌器材 } \\
\text { 使用部門 }\end{array}$} & \multicolumn{5}{|c|}{ 洗浄・滅菌各業務の実施場所 } \\
\hline & & 一次処理 & 洗浄 & 組立・切組 & 包装・シール & 滅菌 \\
\hline \multirow{3}{*}{ [TI $]$} & 手術部 & \multicolumn{5}{|c|}{ 中材部 } \\
\hline & \multirow{2}{*}{ 外来部・病棟 } & \multirow{2}{*}{ 中材部 } & \multicolumn{4}{|c|}{ 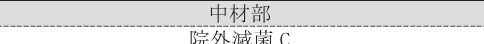 } \\
\hline & & & \multirow{2}{*}{\multicolumn{4}{|c|}{$\frac{\text { 院外滅菌 C }}{\text { 中材部 }}$}} \\
\hline \multirow{4}{*}[\mathrm{GA}]{} & \multirow{2}{*}{ 手術部 } & \multirow{2}{*}{ 手術部 } & & & & \\
\hline & & & & 中材部 & & 院外滅菌 C \\
\hline & \multirow{2}{*}{ 外来部・病棟 } & \multicolumn{5}{|c|}{ 中材部 } \\
\hline & & \multicolumn{4}{|c|}{ 中材部 } & 院外滅菌 C \\
\hline \multirow{3}{*}[\mathrm{KI}]{} & 手術部 & \multirow{2}{*}{\multicolumn{2}{|c|}{ 中材部 }} & \multirow{2}{*}{ 中材部 } & \multirow{2}{*}{\multicolumn{2}{|c|}{ 院外滅菌 C }} \\
\hline & \multirow[b]{2}{*}{ 外来部・病棟 } & & & & & \\
\hline & & & 中材部 & 中材部 & \multicolumn{2}{|c|}{ 院外滅菌 C } \\
\hline \multirow{2}{*}[\mathrm{SI}]{} & 手術部 & \multicolumn{5}{|c|}{ 院外滅菌 C } \\
\hline & 外来部・病棟 & \multicolumn{5}{|c|}{ 院外滅菌 C } \\
\hline \multirow{4}{*}[\mathrm{TS}]{} & \multirow{2}{*}{ 手術部 } & \multirow{2}{*}{ 中材部 } & & & 才部 & \\
\hline & & & & 院外 & 烕菌 C & \\
\hline & 外来部・病植 & 中财部 & & & 才部 & \\
\hline & & 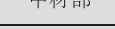 & & 院外 & 葳菌 C & \\
\hline & 手術部 & & T.S.S.U. & & $\begin{array}{l}\text { 包装:T. S. S. U. } \\
\text { 㠺: 中材部 }\end{array}$ & $\begin{array}{l}\text { 中材部 } \\
\text { 院外滅藏 C }\end{array}$ \\
\hline 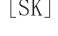 & 处来部 • 病柚 & & & & & 中材部 \\
\hline & 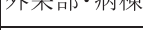 & & & & & 院外滅菌 C \\
\hline [ST] & \begin{tabular}{|l|} 
手術部 \\
\end{tabular} & 手術部 & & & 可部 & \\
\hline$[01]$ & 外来部・病棟 & 中材部 & & 院外 & 烕菌 C & \\
\hline & & & & & 才部 & \\
\hline [SS] & 手術部 & 手術部 & 中材部 & & 院外隇菌 C & \\
\hline & & & & 院外 & 威菌 C & \\
\hline & 外来部・病棟 & 中材部 & & 院外 & 烕菌 C & \\
\hline & 手術部 & 手術部 & 中材部 & & 中忉部 & \\
\hline$[\mathrm{NK}]$ & & & & & $\frac{\text { 院外滅菌 C }}{\text { 中材部 }}$ & \\
\hline & 外来部・病樔 & & & & 院外滅菌 C & \\
\hline & 手術部 & & & 中材部 & & \\
\hline$[\mathrm{TK}]$ & 外来部・病棟 & 中材部 & & & 才部 & \\
\hline & & & & & 威菌 C & \\
\hline
\end{tabular}


滅菌 C の担当者間で、確認が行われていた。

また $[\mathrm{S} \mathrm{K}]$ では、前述のとおり院外滅菌 S 導入により T. S. S. U. を 別途稼偅させることとなったが、中材部の面積は改修前と比較して 約 $119 \mathrm{~m}^{2}(34.7 \%)$ 減少し、T.S. S. U. 設置による面積増加分を加味 しても院内の洗浄 ・ 滅菌業務に要する部分の面積は改修前後を比較 すると約 $25 \%$ 減少している。中材部の面積減少分は、新診療科の立 ち上げに伴う放射線部門の面積増加や、廊下の患者動線の改善に向 けられ、その結果収入増加や患者サービス向上が果たされている。 なお前述のとおり [ T I ] でも同様に中材部の面積を約 $494 \mathrm{~m}^{2}$ (57.6\%) 減少させて、その分を外来化学療法や人工透析部門など の収益の向上が見込まれる部門に転用している。

\section{5.まとめ}

以上、アンケート調査、インタビュー・現地観察調查、文献調查結 果から、導入病院における中材部の運用や建築・装置等の整備状況を 明らかにし、その特性を把握した。まとめると以下のとおりである。

（1）導入病院の属性と中材部の運用・建築・装置等の概況について - 病床規模は中規模の事例が過半数以上、2000 年以降の竣工病院が 多数である。開設主体は国公立が最も多い。平均在院日数は 14.4 日、年間手術件数は 3577.5 件/年で、100 床あたり 878.6 件/年で あった。また非導入病院より、病床規模によらず手術を相対的に 多く実施している様子が示唆された。

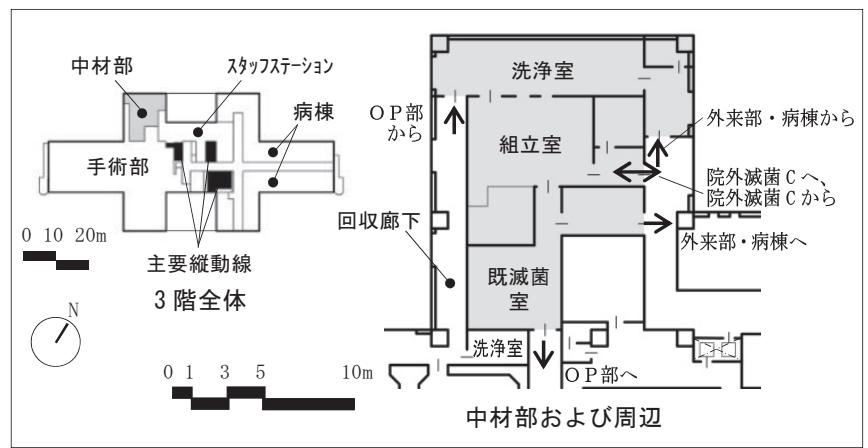

- 中材部担当者の 100 床あたりの平均人数は 2.3 人である。また担 当者の外部委託は、かなり進んでいるか、または外部委託がほと んど進んでいないかに、大きく分かれている。平日の平均稼働時 間は 678.7 分で、非導入病院より相対的に長時間となっている様 子が示唆された。取扱い全器材量に占める手術部用器材量の平均 相対的割合は $52.6 \%$ で、手術部との機能上の関係が外来部や病棟 のそれらより相対的に深く、また非導入病院のそれより深いこと が示唆された。

・ 中材部と手術部との位置関係は、同一階で隣接している病院が最 も多い。中材部の清污区分の考え方に基づくゾーニングは污染・ 中間・清潔の全てのゾーン間を区画している事例が最も多い。中 材部面積の 100 床あたりの平均面積は $64.8 \mathrm{~m}^{2}$ 、延床面積に対する 平均割合は $0.76 \%$ であった WD は $0.40 \sim 0.79$ 台/100 床、AC は 0. 40〜0.79 台/100 床を設置している病院が比較的多い。なお EOG は設置していない病院が多く、PSの 100 床あたりの設置台数はば らつきが大きい。種類別にみた滅菌装置の設置状況は、AC+PS が 最も多い。これらより、導入病院はWDによる洗浄業務量と院内で のPSによる滅菌業務量が相対的に多く、EOGによる滅菌業務量は、 院外滅菌 Cに委託することで相対的に少ないことが推察された。

（2）導入病院事例の中材部の運用・建築 · 装置等の特性について

- 院外滅菌 C について、器材の洗浄・滅菌機能の他に、医療施設の 器材を保管する院外倉庫の機能を有している事例があった。災害 時は、系列施設から器材の融通や院内業務の一時的な請負など、 災害時での委託元医療施設の事業の継続性を担保する取り組みを 行っている。また建築の整備状況から、器材搬出入機能以外は、 医療施設における中材部の建築計画の考え方と大きな差異はない と考えた。装置等の種類についても同様に医療施設の中材部に整 備されているそれらと大きな差違は見られなかった。

・院外滅菌 C 運営業者と院内業務受託業者が同一であれば、中材部 業務が効率・簡素化する可能性がある。また院外滅菌 S 導入時に 滅菌装置台数を減少させ、整備・運用経費を削減している事例が ある一方で、経済上の理由により委託内容を見直して、装置等を

図 $12[\mathrm{~N} \mathrm{~K}]$ における中材部 (3 階)の平面図

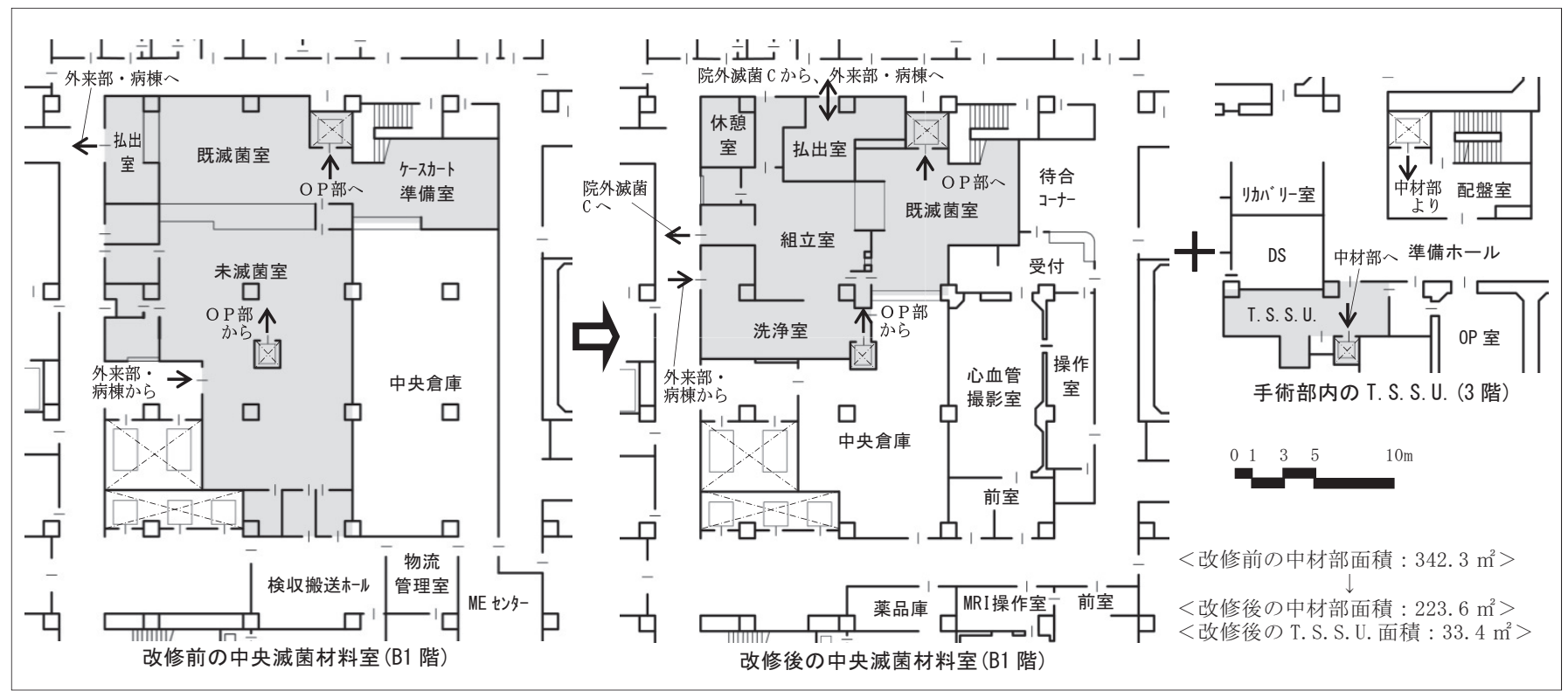

図 13 [S K ] における改修前後の中材部および周辺の平面計画の変化 
増強した事例もみられた。

・取り扱っている器材種類は、酸化エチレンガス滅菌対象器材が主 である。また高圧蒸気滅菌対象器材の一部を委託対象としている 場合は、セット数の多い器材が対象である。委託器材の相対的量 は、病床規模に因らず委託内容により事例毎に異なる。相対的量 が多い事例は、外来部・病棟用器材に加えて手術セット器材も対 象としている。

・大部分の事例で、同一部門で使用している器材でも、種類により 院内で洗浄・滅菌の全工程を行うものと、工程途中から院外滅菌 Cで行うものに分かれている。一部事例では、外来部や病棟で使 用した (一部) 器材は一次処理のみを行った後に、院外滅菌 C 一 搬出されていた。

•院外滅菌 $\mathrm{S}$ 導入を前提とした中材部の計画・設計が行われた $[\mathrm{N} \mathrm{K}]$ では、院外滅菌 C との器材の搬出入のための専用動線を確保して いる。また院外滅菌 S 導入時に中材部の改修を行った $[S \mathrm{~K}][\mathrm{T}$ I ] では、院内の洗浄・滅菌業務に要する部分の面積の減少分を医 業収入増加や患者サービス向上の為の空間に転用されている。

以上を踏まえると、導入病院では病床規模によらず手術が相対的 に多く実施され、それに伴う中材部の運用と共に装置等の合理的な 整備が行われている様子が窺える。また経済的な条件が見合えば、 院外滅菌 C との洗浄・滅菌業務内容や責任の分担を明確にした上で、 従来より簡素な中材部の建築・装置等の整備が実現できると考える。 この中材部の機能縮小に伴う建築空間の減少分を他部門の増強に振 り向け、病院全体の経営環境に好影響を与えることも可能であり、 今後の地域における急性期病院の再編の中で、院外滅菌 $\mathrm{S}$ 導入が一 つの計画手法として有効と考える。

なお、本研究では 200 床以上の病院を分析対象としたため、これ より病床規模が小さい病院についての検討は行っていない。また院 外滅菌 S 導入を前提とした中材部の平面計画の詳細な検討や、手術 件数の増加に対する院外滅菌 S の導入効果注 ${ }^{8)}$ の明確化などは、引き 続き事例を収集して継続的に分析・考察する必要があると考える。

\section{謝辞}

調查にご協力頂いた各病院・院外滅菌 C ご担当者に厚く御礼申し 上げます。なお本研究の一部は、サクラシステムプランニング株式 会社からの平成 23 年度〜 26 年度研究費助成および北海学園平成 26 年度学術研究助成を得て行った。

注

注 1 ）導入病院/非導入病院の病床規模別の 100 床あたりの平均年間手術件数 は下記のとおりである。

\begin{tabular}{l|c|c|c|c}
\hline & 計 & $\begin{array}{c}\text { 小規模 } \\
(200 \sim 299 \text { 床 })\end{array}$ & $\begin{array}{c}\text { 中規模 } \\
(300 \sim 599 \text { 床 })\end{array}$ & $\begin{array}{c}\text { 大規模 } \\
(600 \text { 床 })\end{array}$ \\
\hline 導入病院 & 878.6 件 & 970.5 件 & 827.9 件 & 911.2 件 \\
\hline 非導入病院 & 701.3 & 448.7 & 723.4 & 876.8 \\
\hline
\end{tabular}

注 2 ) 非導入病院 1 事例のみ、中材部だけでなく物品供給部門全体の担当者 人数での回答であったため、本分析の対象外とした。

注 3 ) 他部門用器材より多種少数である手術部用滅菌器材又はこれらで構成 される手術セットが不足した場合は緊急で滅菌を行う必要がある。そ の際は、他の滅菌法より相対的に短時間で行うことができるPSを用い た滅菌が行われることが多い。これより、導入病院では100床あたりの 平均年間手術実施件数が相対的に多く、取扱い全器材量に占める手術 部用器材量の相対的割合が高いことから、PSによる滅菌業務を行う必
要性が高く、業務量も多くなっていると考えられる。

注 4 ）建築基準法第48条関連の別表第二における建築物の用途の位置付け。

注 5 ) 院外滅菌Cへのインタビュー調査の結果、酸化エチレンガスに毒性があ ることや、EOGによる滅菌は1回あたりに要する時間が相対的に長時間 であることなどから、医療施設が院内で業務を行うことを避けて院外 滅菌C一業務を委託する例が増加していることが明らかになった。

注 6 ) Theater Sterile Supply Unit：手術部専用中材部のこと。

注 7 ) 院内で洗浄業務を請け負っている業者と院外滅菌Cの運営している業者 が異なると、院内での洗浄業務の実施方法や洗浄管理や品質などを、 院外滅菌C側業者は正確には把握できない。器材の洗浄・滅菌不良が原 因で患者への感染などの問題が発生することも考え、院外滅菌C側業者 は、院内に搬送されてきた器材を二度手間を承知でもう一度洗浄し、 その結果作業の効率性が低下する。

注 8 ) 導入病院へのインタビュー調査の結果、本文で示した効果以外に「中 材部業務担当者の人件費の圧縮」「装置等の購入や減価償却費の制御」 $\lceil E 0 G$ 等の維持管理負担の軽減」「器材の滅菌管理・品質の保持・向上」 「手術部看護師の本来業務への専念」「使用部門が異なる器材の混在の 減少」「中材部業務の効率化」などの多様な意見を得た。

\section{参考文献}

1 ）病院建築, No. $86 \sim 145$, 日本医療福祉建築協会 (旧 日本病院建築協会), 1990. $1 \sim 2005.1$

2 ）医療福祉建築, No. 146 173, 日本医療福祉建築協会, 2005. 4 2011. 10

3 ）保健·医療・福祉施設建築情報シート集 1996 2011, 日本医療福祉建築協 会, $1996.9 \sim 2011.9$

4) 中野明：病院における物品供給部門のSPD化からみた平面計画, 病院にお ける物品供給部門の建築計画に関する研究 その1, 日本建築学会計画系 論文集，No. 534,pp. 95-100, 2000.8

5 ) 田口正生 : 綜合病院の中央材料室の計画について, 日本建築学会論文報 告集, No. 57, pp. 89-92, 1957.7

6 ）伊藤誠, 幡野公人：医療材料の流れと中央材料室の位置づけ，病院の建 築計画に関する研究, 日本建築学会論文報告集, No. 159, pp. 75-91, 1969.5

7 ) 池田有隣, 上田恭嗣：中央滅菌材料室の建築計画に関する研究（私立医 科大学附属病院の調査・分析), I . 平面計画, 日本建築学会近畿支部研 究報告集, 計画系, No. 16, pp. 249-252, 1976.6

8 ）上田恭嗣, 池田有隣：中央滅菌材料室の建築計画に関寸る研究（私立医 科大学附属病院の調査・分析), II . 面積の構成・その他, 日本建築学会 近畿支部研究報告集, 計画系, No. 16, pp. 253-256, 1976.6

9 ) 小野山博, 池田有隣, 上田恭嗣：中央滅菌材料室の建築計画に関寸る研 究 (私立医科大学附属病院の調査・分析), III. 医療設備・材料, 日本建 築学会近畿支部研究報告集, 計画系, No. 16, pp. 257-260, 1976.6

10）上田恭嗣，池田有隣：中央滅菌材料室の建築計画に関寸る研究IV, 日本 建築学会近畿支部研究報告集, 計画系, No. 17, pp. 129-132, 1977.5

11）中野明：建築計画からみた中央化における中材部門の位置づけ, 病院設 備, Vol.22, No. 2, pp. 21-25, 1980.3

12）中野明：中央滅菌材料部の機能と建築計画, 病院設備, Vol. 26, No. 5, pp. $10-17,1984.9$

13）中野明：感染管理に配慮した中央滅菌材料部の計画と運用, 病院設備, Vol. 43, No. 5, pp. 91-100, 2001.9

14）辻吉隆：新しい感染管理に基づく手術部・ICU - 中央材料滅菌部の計画, 病院建築, No. 136, pp. 8-11, 2002.7

15）日本医療機器学会監修, 小林寛伊編：改訂第4版医療現場の滅菌, 一るす 出版, 2013. 10

16）若松亮佑，黒松祐子，中野明，石橋達勇：中央滅菌材料部の平面計画に 関する調査研究, 中央滅菌材料部の計画と運用に関する建築計画的研究 その1, 日本建築学会大会学術講演梗概集, 建築計画, pp. 377-378, 2012.9

17）保健·医療・福祉施設建築情報シート集 2010 , 日本医療福祉建築協会, 2010. 9 


\section{A STUDY ON THE PLANNING AND MANAGEMENT \\ OF THE CENTRAL STERILE SUPPLY DEPARTMENT \\ IN ACUTE HOSPITAL HAVING INSTALLED OFF-SITE STERILIZATION SERVICE}

\section{Tatsuo ISHIBASHI* and Akira NAKANO**}

\footnotetext{
* Prof., Dept. of Architecture and Building Engineering, Faculty of Engineering, Hokkai-Gakuen University, Dr.Design ** Dept. of Living Space Design, Faculty of Contemporary Human Life Science, Tezukayama University, Dr.Eng.
}

This paper describes the characteristics of planning and management of the central sterile supply department (C.S.S.D.) in acute hospital having installed off-site sterilization service based on the results of questionnaire, interview, observation and literary survey.

(1) Outline of C.S.S.D. planning and management

- Based on the unit requirement of the annual number of surgical procedures, procedures will be conducted relatively more often regardless of hospital scale from hospitals without off-site sterilization service installed.

- Mean operating time at weekdays were found to be relatively longer than at hospitals without off-site sterilization service installed. The mean proportion of surgical sterilization instruments out of all instruments handled demonstrated that there was a stronger functional relationship between the C.S.S.D. and the surgical department than that between the outpatient department and wards, and this relationship was deeper than that observed at hospitals without off-site sterilization service installed.

- Based on the state of installation of cleaning and sterilization machines, instruments were sterilized using autoclave (AC) mainly, and there were relatively more cleaning duties with washer-disinfector and sterilization duties with gas plasma sterilization than at hospitals without off-site sterilization service installed, and duties with ethylene oxide gas sterilization were relatively few due to outsourcing duties to off-site sterilization service center.

(2) C.S.S.D. planning and management characteristics

- [GA]-C had the function of off-site warehouse in addition to cleaning and sterilization. Most of off-site sterilization service centers had worked on securing business continuity in hospitals having installed off-site sterilization service at disaster. The state of architectural planning and the type of cleaning and sterilization machines at off-site sterilization service centers, weren't remarkably different from those at C.S.S.D.

- If the business operating the off-site sterilization service and the business to which in-hospital duties have been outsourced are the same, duties could be made more efficient and simplified. There have been cases in which the number of sterilization machine installed has been reduced upon introduction of off-site sterilization service, thereby cutting maintenance and operation costs. There have also been cases in which outsourcing content has been reviewed from an economic viewpoint and cleaning and sterilization machines have actually been reinforced.

- The main types of instruments for which cleaning and sterilization is outsourced to off-site sterilization service center are instruments for ethylene oxide gas sterilization. When some instruments are also outsourced for steam sterilization, instruments with larger set numbers are targeted. Relatively common cases for outsourcing are surgical set instruments in addition to outpatient department and ward instruments.

- For most cases, even instruments used in the same department might either have all cleaning and sterilization processes conducted within the hospital or have processes form a certain stage conducted at off-site sterilization service center depending on the type. For some cases, instruments used at outpatient departments and wards undergo only prewashing before being transported to the off-site sterilization service center.

- [NK] has ensured a specialized traffic line for the instruments in and out of the C.S.S.D.. [SK][TI] which modified the C.S.S.D., have diverted the areas for cleaning and sterilization to spaces for increasing medical income and improving patient services.

(3) Conclusions

- Hospitals having installed off-site sterilization service conduct a high number of surgical procedures in relation to the number of beds. At the C.S.S.D., management and the rational maintenance of cleaning and sterilization machines, are being conducted in accordance with the situation.

- As fit the economic conditions, cleaning, sterilization and responsibilities could be allocated between the C.S.S.D. and off-site sterilization service center to make it possible to plan and to maintain the machines of simpler C.S.S.D. than previously. 